\title{
Partial Replacement of Limestone and Silica Powder as a Substitution of Cement in Lightweight Aggregate Concrete
}

\author{
Seyed Alireza Zareei ${ }^{\mathrm{a}}$, Farshad Ameri ${ }^{\mathrm{b}}$, Farzan Dorostkar ${ }^{\mathrm{b}}$, Shahriar Shiran ${ }^{\mathrm{b}}$ \\ ${ }^{a}$ Department of civil engineering, Isfahan (Khorasgan) Branch, Islamic Azad University, Isfahan, Iran. \\ ${ }^{b}$ Member of Scientific Association of Civil Engineering, Isfahan (Khorasgan) Branch, Islamic Azad University, Isfahan, Iran .
}

Received 01 August 2017; Accepted 27 September 2017

\begin{abstract}
With increasing trends towards the broader usage of concrete and warning depletion of natural resources of aggregates, it seems reasonable to find mineral additives or binding materials of different types as ingredient of concrete. Accordingly, wide usage of light weight concrete lies on some main structural applications as reduction of total dead, seismic loads, environmental pollution, and labour cost. This paper tries to investigate the properties of light weight blended concrete containing lime stone powder (LP), micro-silica (MS), pumice, and leca in various proportioning rateing as a partial replacements of cement. Utilization of these additives on the compressive strength, tensile strength, water absorption coefficient, acid resistance, and impact resistance examined experimentally in various curing conditions at the ages of 7 and 28 days to evaluate the combined effect of micro-silica and lime stone incorporation on strength and durability properties of light weight concrete, along with introduction of optimum replacements. For this purpose, 10 lime-stone based concrete mixtures were prepared with proportions from 0 to $20 \%$, and constant values of $10 \%$ micro-silica and w/c ratio. From the results, it was indicated that addition of lime stone powder in concrete reduces short-term properties as well as the compressive strength. Optimum levels of powder replacements can serve as sustainable and durable concrete, also environmental and economic benefits.
\end{abstract}

Keywords: Limestone Powder; Micro-Silica; Pumice; Leca; Structural Light Weight Concrete.

\section{Introduction}

The growing demand for concrete lies on some issues as low costs of constituent materials, construction and maintenance of concrete structures [1]. It was reported that in 2002 about 6.5 billion tonnes of concrete were produced all around the world [2] or annual production of concrete is up to 10 billion tonnes [3]. There may be an estimation to concrete production growing rate up to 18 billion tonnes by 2050 [4]. One of the main reasons of global warming may be attributed to concrete industry by emission a high volume of $\mathrm{CO} 2$ into the atmosphere [5, 6]. In recent years, principal applications of technological advancements have translated into elaborated studies on properties and behaviors of materials, to achieve favorable strength, durability as well as workability. The process of selecting suitable ingredients of concrete and determining their relative amount with the objective of producing a concrete as economically as possible is well known in many studies, the major part of the energy consumption is related to the Portland cement formation $[7,8]$.

The general term light weight (LW) concrete refers to any concrete which is produced to an oven dry density of less than $2000 \mathrm{~kg} / \mathrm{m}^{3}$ [8]. Any aggregate with a particle density of less than $2000 \mathrm{~kg} / \mathrm{m}^{3}$ or dry loose bulk density of less

\footnotetext{
* Corresponding author: a.r.zareei@khuisf.ac.ir

DOI: http://dx.doi.org/10.21859/cej-03099
}

$>$ This is an open access article under the CC-BY license (https://creativecommons.org/licenses/by/4.0/).

(C) Authors retain all copyrights. 
than $1200 \mathrm{~kg} / \mathrm{m}^{\wedge} 3$ Is defined as light weight [9]. Using lightweight aggregates (LWA) is one of the most typical methods of fabricating structural light weight aggregate concrete [10]. The main advantages of LWA are: reducing dead load, seismic imposed loads, acceleration volume of excavation and construction wastes, concrete demand at bases, and so on. These categorizes divided into sub-categories for example, dead load reduction is related to reducing total size of the structure, also columns, beams, foundation, roof thickness, and reinforcements [11, 12]. In another study Akeiber et al. (2016) stated that lightweight floors and walls considerably reduce the interior temperature of the room to make the occupants more comfortable [13]. Lightweight aggregates are broadly classified in to two types: natural (pumice, diatomite, volcanic cinders, etc.) And artificial (perlite, expanded shale, clay, slate, sintered PFA, etc.) [14].

There has recently been a trend in literatures to allow supplementary materials or by-products to be used as partial replacements of cementitious materials in concrete production as one way to reduce pollution and environmental disturbances, while offering complementary properties to compensate natural aggregate loss in concrete. Therefore, cement replacements in concrete can be highly beneficial regarding cost, energy efficiency, low permeability, strength and durability $[15,16]$. Kasselouri 1977 stated in early works that the use of industrial by-products, such as FA, SF, offers a low-priced solution to the environmental problem of depositing industrial waste. Research works in this regard have proved that inclusion of these pozzolanic materials not only improves the strength and durability of concrete but also can be considered helpful in reducing global warming caused by disposal of waste materials [17].

In some parts of the world lime stone powder has been used for many years, but has received the growing interest globally, especially in Europe in recent twenty years [18, 19]. Addition of limestone possibly reduces the initial and final setting time, also its porosity [20].

Ajay \& Rajeev 2012 reported that silica fume possibly increases the strength of concrete up to $25 \%$, while decrease the voids in concrete, capillary, absorption and porosity of concrete due to fine particles of silica fume react with lime present in cement. Silica fume is much cheaper than cement [21] so it reduces the final cost of concrete production. Silica powder (quartz) addition into concrete as a partial replacement of cement has been investigated generally by comparing its performance to that of a similar-sized limestone powder [22-25].

This study aimed to investigate the mechanical and durability properties of light weight aggregate concrete containing limestone and silica powder in different proportions at 7 and 28 days of curing.

\section{Methodology}

With regard to the abovementioned review of the previous literature, consistent interpretation of test data requires a well-defined formation process of samples and test set up. Simultaneous combined effect of lime stone powder and micro-silica as partial replacement of cementitious materials was evaluated experimentally in light weight concrete in different proportions with constant $\mathrm{w} / \mathrm{c}$ ratio of 0.37 . It should be noted that micro-silica addition likely to prevent strength decrease in powdered limestone concrete. Regarding light weight aggregates utilization on concrete performance, five mixtures were provided using an artificial light weight aggregate and five mixtures using a natural light weight aggregate. Samples were designed in cube, cylindrical and beam forms and demoulded after 24 hours, then fully saturated in water tank at $23^{\circ} \mathrm{C}$ to have 7 and 28 days compressive strength, impact resistance, water absorption and acid resistance experimentally.

\subsection{Materials}

Materials used in this study consists of ordinary cement, sand, coarse aggregates of leca and pumice, powdered limestone, and micro-silica, brief definitions of each are presented below.

\subsubsection{Cement}

Among different types of cements, locally available Shahrekord type II cement for our evaluation used, with physical properties and chemical analysis composition given in the following tables:

Table 1. Physical properties of cement used in the present study

\begin{tabular}{ccccc}
\hline Property & $\begin{array}{c}\text { density } \\
\left(\mathbf{g} / \mathbf{c m}^{\mathbf{3}}\right)\end{array}$ & $\begin{array}{c}\text { Characteristic surface blain } \\
\left(\mathbf{c m}^{\mathbf{2} / \mathbf{g})}\right.\end{array}$ & $\begin{array}{c}\text { 28 days compressive strength } \\
(\mathbf{M p a})\end{array}$ & $\begin{array}{c}\text { Bulk density } \\
\left(\mathbf{g} / \mathbf{c m}^{\mathbf{3}}\right)\end{array}$ \\
\hline Value & 3.19 & 3420 & 40.3 & 1.13 \\
\hline
\end{tabular}

Table 2. Chemical analysis of cement

\begin{tabular}{ccccccccccc}
\hline Cao & Arts, & Mgo & Al2o3 & Fe2o3 & So3 & K2O & Na2O & Tio2 & P205 & LOI \\
\hline 61.2 & 21.7 & 4.78 & 3.47 & 2.53 & 2.58 & 0.98 & 0.14 & 0.04 & 0.65 \\
\hline
\end{tabular}




\subsubsection{Micro-Silica}

The initial interests considering the evaluation of concrete performance containing micro-silica as a partial replacement of cement has been prompted by strict enforcement of air-pollution controls in various countries mostly aimed to stop release of the material into the atmosphere. Silica fume is typically known to produce a high-strength concrete which can be used in two different ways, one as a cement replacement to reduce the cement content (usually for economic reasons); and as an additive to improve concrete properties [26].

The main influences of micro-silica super plasticizer incorporation into concrete can be summarized in to: less mechanical strength, less permeability, improving paste-to-aggregates bond due to reduction of weak transition zone between paste and aggregates, reduction of chloric ions movement, prevention from reinforcement corrosion in reinforced concretes, reduction of internal exothermic rate, providing high early strength and durability, and decrease air pollution.

Micro -silica differs with other plasticizers whose efficiency relative to unit weight is 2-4 times more than that of cement, while partial replacement of cement by low percentage of micro-silica leads to internal heat reduction. Any change occurs in the mechanical properties of concrete means to the changes in long-term service of the binder hydration. The cement hydration caused by chemical reactions of Portland cement and water leads to the formation of hydrated cement paste that can be effective on the concrete strength.

Table 3. Mechanical and chemical properties of micro-silica pozzolan

\begin{tabular}{cccccccc}
\hline $\begin{array}{c}\text { Particle size } \\
(\boldsymbol{\mu m})\end{array}$ & $\begin{array}{c}\text { Density } \\
\left(\mathbf{k g} / \mathbf{m}^{\mathbf{3}}\right)\end{array}$ & $\mathbf{F e 2 O 3}$ & $\mathbf{A L 2 O 3}$ & K2O & Cao & Mgo & Sio2 \\
\hline $0.6-00.45$ & $550-650$ & 0.89 & 1.32 & 0.21 & 0.26 & 0.71 & 96.6 \\
\hline
\end{tabular}

\subsubsection{Lime Stone Powder}

The grey and black stone, formulated with accumulation of volcanic ashes and gradual cooling along with expansion due to bubbles caused by vapor and going gases. It is found in various ingredient sizes of about fly ashes to larger particles of size beyond $100 \mathrm{~mm}$, per with different beneficial effects. Limestone powder is a kind of super-fine material with size normally smaller than $5 \mu \mathrm{m}$, which is produced by grinding of limestone. Limestone powder can react with hydration products of cement in the hydration process of cement-based material, producing $\mathrm{C} 3 \mathrm{~A} \cdot 3 \mathrm{caco} 3 \cdot 32 \mathrm{H} 2 \mathrm{O}$ and C3A-caco3 11 H2. S.H.[27].

Two decades elapsed since the development of lime stone - filler blended cement. Owing to large numbers of stone cuttings in Iran, and considering substantial increase in generated wastes from the industry, this huge amount of powdered limestone could rather to be used as by-product or partial replacement of cement, even to satisfy local requirements. The results of chemical analysis of stone powder are tabulated in Table 4.

Table 4. Chemical analysis of stone powder

\begin{tabular}{ccccccccccccc}
\hline Cao & Sio2 & Mgo & $\mathbf{A l 2 O 3}$ & Fe2O3 & SO3 & K2O & Na2O & Tio2 & P2O5 & LOI & Blaine & Specific gravity \\
\hline 54.02 & 1.5 & 0.36 & 0.25 & 0.26 & 0.06 & 0.08 & 0.04 & 0.05 & 0.01 & 41.07 & 334 & 2.75 \\
\hline
\end{tabular}

When the content of limestone powder is $10 \%$, the strength of ultra-high performance concrete decreased little, which indicates that we can reduce the cost of the ultra-high performance concrete [28]. In an article, it was also reported that filler blended cements with the content of $10 \%$ powdered limestone showed less strength compared to the reference sample that even increased in later ages. In another study, it has been revealed that concrete contains $10 \%$ limestone powder as a partial replacement of cement may have compatible properties (durability and compressive strength) in comparison with ordinary Portland cement [29].

\subsubsection{Super Plasticizer}

Poly- carboxylic super plasticizer was used with relative solid components of $47 \%$, was produced by Panta Company. Super plasticizer based mixes benefits in lower water demand, more followability of concrete particles, and hydration improving at different ages.

\subsubsection{Light Weight Aggregate Leca}

A part of this investigation allocated to expanded clay coarse aggregate (leca) with rounded and rough appearance, brown pores on microscopic surface, and black cellular inner part. In general, the procedure of mix design containing leca fall in to the stage of clay expansion in rotatory kilns with $1200^{\circ} \mathrm{C}$, with the sizes were between 0 to $32 \mathrm{~mm}$. Benefits 
of coarse aggregates leca such as light weigh, low thermal conductivity, enough acoustic loss, chemical long lasting was made this type of artificial aggregate more and more functional in building, agricultural, environmental and road pavement sections. Regarding cohesion and resistance, light weight concrete leca may be used for the following applications as space filler, insulator or load bearing by in-site casting or to be used as blocks or prefabricated elements.

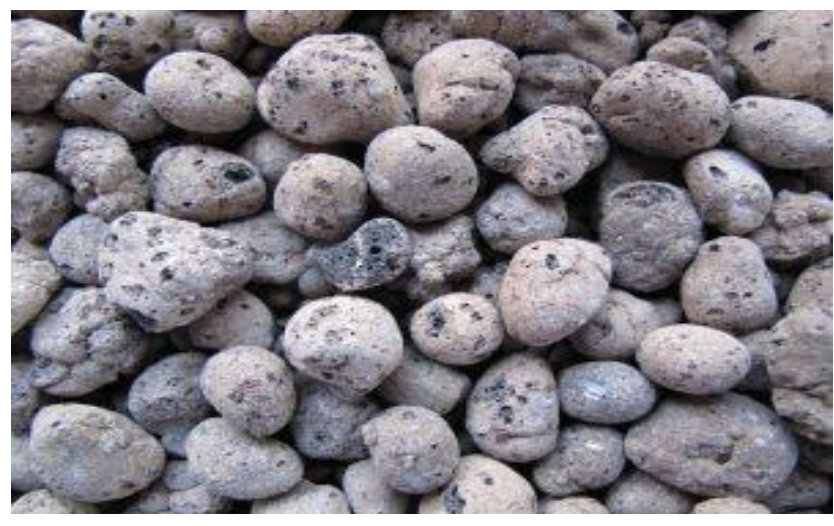

Figure 1. Light weight aggregate leca

Table 5. Chemical analysis of leca and pumice aggregates

\begin{tabular}{ccc}
\hline Chemical compounds & Leca aggregates & Pumice aggregates \\
\hline $\mathrm{Sio} 2$ & $66.05 \%$ & $60.8 \%$ \\
$\mathrm{AL} 2 \mathrm{O} 3$ & $16.57 \%$ & $17.0 \%$ \\
$\mathrm{Fe} 2 \mathrm{O} 3$ & $7.10 \%$ & $3.40 \%$ \\
$\mathrm{Cao}$ & $2.46 \%$ & $3.5 \%$ \\
$\mathrm{Mgo}$ & $2.99 \%$ & $2.5 \%$ \\
$\mathrm{Tio} 2$ & --- & $0.49 \%$ \\
$\mathrm{P} 2 \mathrm{O} 5$ & $0.21 \%$ & $0.47 \%$ \\
$\mathrm{Mno}$ & --- & $0.04 \%$ \\
$\mathrm{SO} 2$ & $0.03 \%$ & --- \\
$\mathrm{Na} 2 \mathrm{O}$ & $0.69 \%$ & $3.8 \%$ \\
$\mathrm{~K} 2 \mathrm{O}$ & $2.69 \%$ & $2.31 \%$ \\
$\mathrm{~L} . \mathrm{O} . \mathrm{I}$ & $0.84 \%$ & $5.62 \%$ \\
\hline
\end{tabular}

\subsubsection{Light Weight Aggregate Pumice}

Using pumice with different workability can be found on account of some properties as low specified weight, compaction strength, elastic coefficient, resistance and insulation toward the action of fire up to $760^{\circ} \mathrm{C}$ without any considerable change in form and volume, and suitable thermal coefficient allowing addition of this material in concrete production, prefabricated components, and using as a fine filler. Primary addition of pumice in manufacturing process of prefabricated components is likely to reduce structural weight, concrete and ironware consumption, and minimizing human causalities in earthquake events.

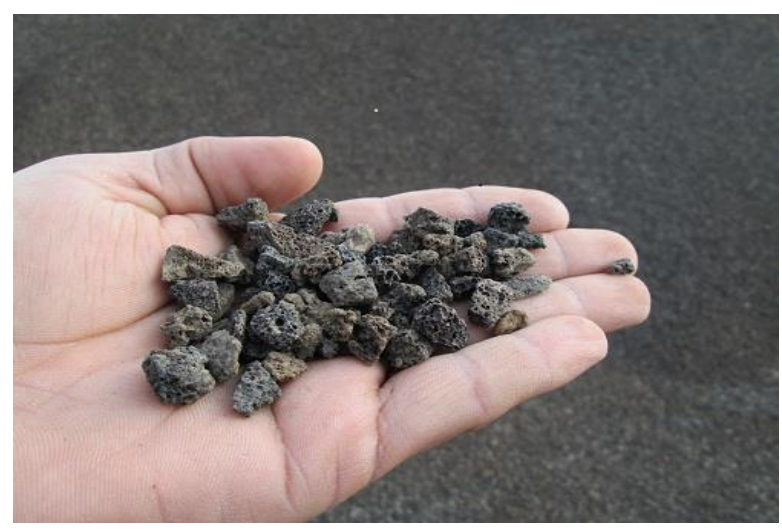

Figure 2. Light weight aggregate pumice 
Table 6. Comparison the properties of aggregates

\begin{tabular}{|c|c|c|c|c|c|c|c|c|c|}
\hline & \multirow{2}{*}{\multicolumn{3}{|c|}{$\begin{array}{c}\text { Water absorption } \\
\text { (mass ratio) }\end{array}$}} & \\
\hline & & & & & & & & & \\
\hline Type & Aggregates & Form/ Plan & $\begin{array}{c}\text { Production } \\
\text { Method }\end{array}$ & $\begin{array}{c}\text { Raw } \\
\text { Materials }\end{array}$ & $24 \mathrm{H}$ & 60 Min & 30 Min & Bulk Density & $\begin{array}{c}\text { Granular } \\
\text { Density }\end{array}$ \\
\hline Natural & Pumice & Irregular & Mechanical & Pumice & $20-40$ & $20-30$ & $10-20$ & $500-800$ & 900-1900 \\
\hline Artificial & Leca 700/ Iran & Rounded & Rotatory kiln & Expanded clay & 6.8 & 5.5 & - & $580-700$ & $1300-1500$ \\
\hline
\end{tabular}

\section{Casting, Testing and Curing of Specimens}

Using a mixer of 50 litres capacity, initially dry materials were added for two minutes' rotation, then $50 \%$ of water and all of the cementitious materials were added for another 3 minutes mixing, finally remained water and the superplasticizer were added, the amount of which determined by the required workability to establish a favorable mixture. Proportioning rates by percentage are summarized in Tables 7 and 8 . After 24 hours of casting, the specimens were all demoulded and then were immersed in cold water tank by $23{ }^{\circ} \mathrm{C}$.

Table 7. Light weight concrete blended with leca $\mathrm{kg} / \mathrm{m}^{2}$

\begin{tabular}{|c|c|c|c|c|c|c|c|c|}
\hline Mix plan & $\mathbf{W} / \mathbf{b}$ & $\begin{array}{c}\text { Lime stone powder } \\
(\%)\end{array}$ & Cement & $\begin{array}{l}\text { Micro-silica } \\
\quad(\%)\end{array}$ & Water & $\begin{array}{c}\text { Coarse } \\
\text { aggregates }\end{array}$ & $\begin{array}{l}\text { Ordinary } \\
\text { sand }\end{array}$ & Super-plasticizer \\
\hline $\mathrm{LM} 0=\mathrm{CTL}$ & & 0 & 450 & & & & & \\
\hline LM5 & & 5 & 430 & & & & & \\
\hline LM10 & 0.37 & 10 & 410 & 10 & 184 & 360 & 540 & 10 \\
\hline LM15 & & 15 & 390 & & & & & \\
\hline LM20 & & 20 & 370 & & & & & \\
\hline
\end{tabular}

Table 8. Light weight concrete blended with pumice $\mathrm{kg} / \mathrm{m}^{2}$

\begin{tabular}{|c|c|c|c|c|c|c|c|c|}
\hline Mix plan & $\mathbf{W} / \mathbf{b}$ & $\begin{array}{c}\text { Lime stone powder } \\
(\%)\end{array}$ & Cement & $\begin{array}{c}\text { Micro-silica } \\
(\%)\end{array}$ & Water & $\begin{array}{c}\text { Coarse } \\
\text { aggregates }\end{array}$ & $\begin{array}{l}\text { Ordinary } \\
\text { sand }\end{array}$ & Super- plasticizer \\
\hline $\mathrm{PM} 0=\mathrm{CTL}$ & & 0 & 450 & & & & & \\
\hline PM5 & & 5 & 430 & & & & & \\
\hline PM10 & 0.37 & 10 & 410 & 10 & 184 & 360 & 540 & 10 \\
\hline PM15 & & 15 & 390 & & & & & \\
\hline PM20 & & 20 & 370 & & & & & \\
\hline
\end{tabular}

\subsection{Mixture Proportions}

Ten series of mix proportions of which one control and nine with different proportions of mineral additives were prepared here, the amount of w/b ratio was kept constant at 0.37 in all mixes. Of each mix plan, 6 cube specimens of $10 \times 10 \times 10 \mathrm{~mm}$ size were prepared, and the compressive strength, bending strength, impact resistance, water absorption ratio, chloride ions penetration, and tensile strength measurements were made on them. After hardening state by half an hour, each three of the specimens were cured at 7 and 28 days, respectively. Tensile strength test performed at 7 and 28 days of curing on two concrete columns $(10 \times 10 \times 50 \mathrm{~mm})$ obtained from each mix plan.

\subsection{Compressive Strength Test}

Several attempts were made to evaluate the compressive strength in various ages of concrete. After cold water curing at $23^{\circ} \mathrm{C}$, then specified dry weight and short term water absorption calculations were calculated. Using hydraulic jack, as it can be seen in Figure 3, compression strength is obtained. Loading protocol is according to the hydraulic jack specification (ELE ADR-Auto V2.0 2000 standard compression). The results are presented in Table 9. The results can be interpreted that increase in lime-stone powder incorporation at 7 and 28 days of curing subsequently decrease the compressive strength of both types of leca and pumice concretes by $10 \%$, after that progressive increase could be observed (except for $20 \%$ incorporation of limestone powder in leca based concrete that cause higher levels of the compressive strength compared to the reference sample and a growing rate may be expected for this type of concrete). 
Table 9. Results of the compressive strength test

\begin{tabular}{cccc}
\hline Mixtures & $\begin{array}{c}\text { Compressive strength at } \mathbf{7} \\
\text { days of curing (Mpa) }\end{array}$ & $\begin{array}{c}\text { Compressive strength at 28 } \\
\text { days of curing (Mpa) }\end{array}$ & Density $\left(\mathbf{k g} / \mathbf{m}^{\mathbf{3}}\right)$ \\
\hline PM0 & 48.82 & 54 & 1870 \\
PM5 & 36.52 & 44.87 & 1778 \\
PM10 & 26.62 & 36.61 & 1788 \\
PM15 & 34.48 & 40.6 & 1832 \\
PM20 & 35.26 & 42.3 & 1846 \\
\hline
\end{tabular}
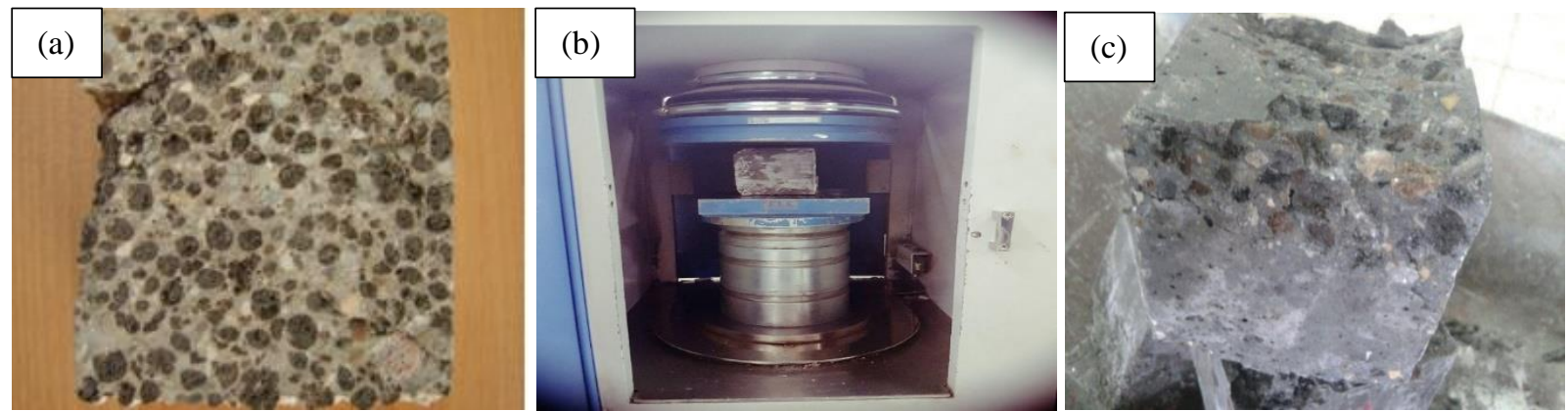

Figure 3. a) The compressive strength test; b) Specimen's failure caused by loading was applied by standard hydraulic jack (ELE); c) Cracked section of light weight leca based concrete

How the compressive strength vary by the dimensions of specimens is of importance, the compressive strength of cylindrical specimens at the age of 28 days reached $80 \%$ of that of a cube specimen by $150 \mathrm{~mm}$ dimension and $83 \%$ of cube specimens with $200 \mathrm{~mm}$ diameter. It should be bore in mind that the compressive strength of light weight aggregate concrete specimens did not vary substantially related to size variations. The results of compressive strength tests can be observed in Table 10.

Table 10. Results of the compressive strength test

\begin{tabular}{cccc}
\hline $\begin{array}{c}\text { Mixture } \\
\text { proportions }\end{array}$ & $\begin{array}{c}\text { Compressive strength at } \\
\mathbf{7} \text { days of curing }\end{array}$ & $\begin{array}{c}\text { Compressive strength at } \\
\text { 28 days of curing }\end{array}$ & Density \\
\hline LM0 & 24.47 & 35.74 & 1570 \\
LM5 & 23.39 & 33.82 & 1434 \\
LM10 & 20.62 & 28.21 & 1446 \\
LM15 & 22.36 & 30.71 & 1502 \\
LM20 & 25.97 & 37.23 & 1558 \\
\hline
\end{tabular}

Excess limestone powder addition (optimal level obtained here by 20\%), is the reason that the amount of fine particles increases up to the level that cement paste lose its capacity to coat all fine and coarse particles leads to drop in the reactive clinker component and significant physical modifications of the material [30].

\subsection{Specified Oven Dry Weight}

The major features of light weigh concrete contains durable ingredients in spite of mass degree less than $2000 \mathrm{~kg} / \mathrm{m}^{3}$ Is the compressive strength beyond $17 \mathrm{MP}$. Combination of light weigh aggregates- as leca or pumice at different proportions possibly compensate this weight problem. Oven dry test conducted by putting the first three cube specimens in oven dry, to be weighted precisely after that, as it can be seen in Figure 4. Necessary care was taken to specimens with predetermined size, volume and shape that can be established using calipers. The results clearly indicate significant weight loss in leca and pumice concretes when cement partially replaced by lime-stone powder, whereby dry weight increased with an increase in replacement levels of lime stone (in percentage), by average. Slight changes in dry weight can be traced in replacement of cement by $20 \%$ lime- stone powder compared to the reference sample 


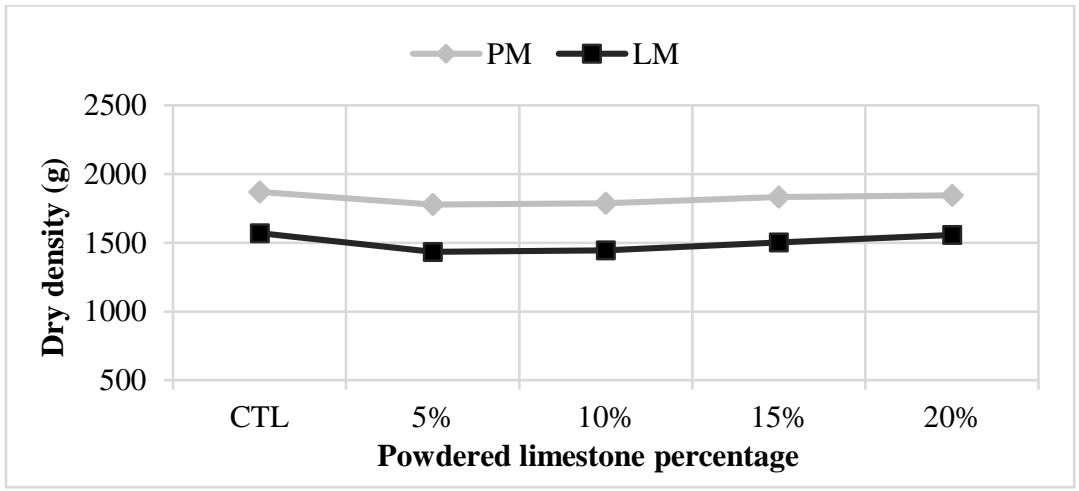

Figure 4. Oven dry weight calculations for pumice and leca based concrete (g)

\subsection{Three - Point Bending Test}

For experimentally evaluating concrete tensile strength in tensile due to bending condition, a simple standardized test can be conducted. The test set up consists of a concrete column of dimensions $10 \times 10 \times 50 \mathrm{~mm}$ adjusted to be placed on the surface of two supports, then two identical loads were imposed in an interval of one third of the length of the beam from the support until crack occurrence. It was indicated that the tensile strength measurement corresponds to the relation of stress/tension due to bending. Bending strength defined by fracture modules. The results are presented in Figure 5 .

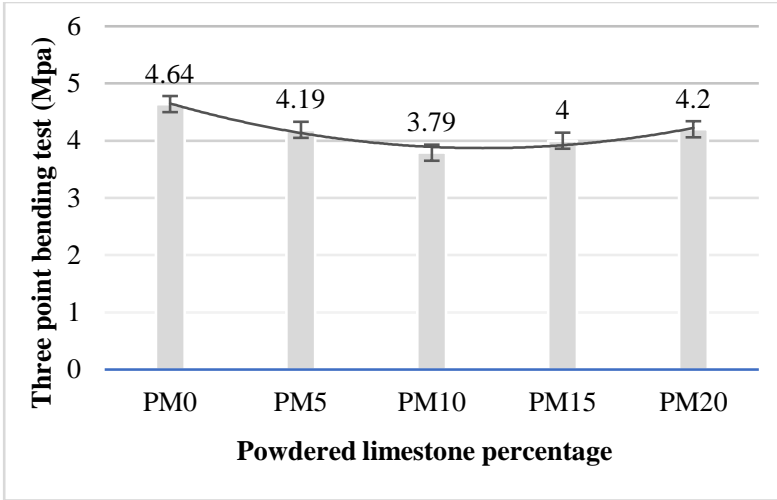

(a)

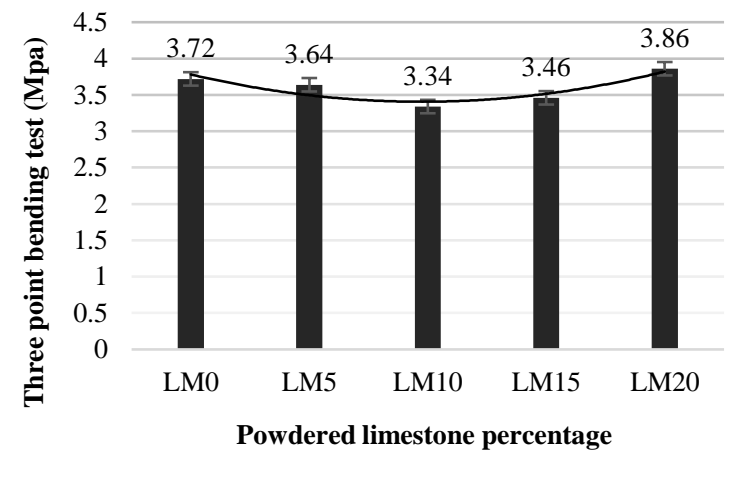

(b)

Figure 5. a) Results of the three-point bending test on pumice based concrete at $28 \mathrm{~d}$ of curing (Mpa); b) Results of the three-point bending test on leca based concrete at $28 \mathrm{~d}$ of curing (Mpa)

As it can be seen from the figures, when lime-stone powder addition increased by $20 \%$, thereby, the three-point bending strength of pumice based concrete samples decreased up to $9.5 \%$ than that of reference sample. This is opposed to the results obtained by leca concrete whose given strength initially decreased, then an increase by to 3.7 was observed in LM20 contains $20 \%$ lime stone powder, compared to the reference sample. In the following figures the relation between three- point bending strength and the compressive strength of specimens is provided for both types of concrete samples.

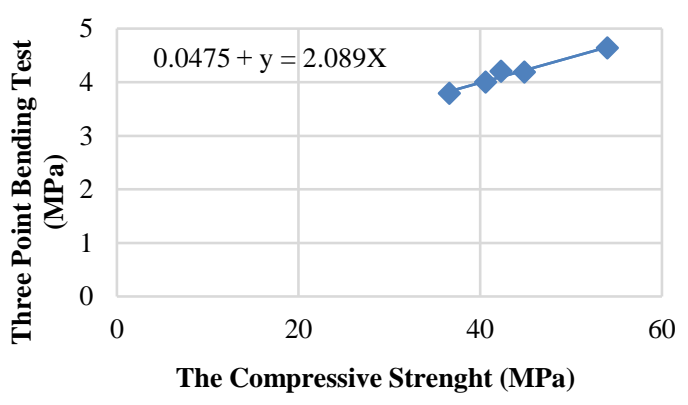

(a)

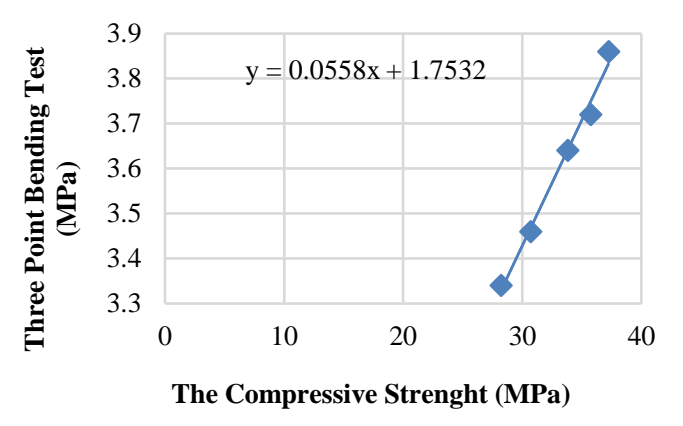

(b)

Figure 6. a) The relation between bending and compressive strength of pumice based concrete; $b$ ) the relation between bending and compressive strength of leca based concrete 


\subsection{Durability Test (Short Term Water Absorption)}

The material gets more vulnerable in hardening phase once the porosity of specimen is closed or residual water gets evaporated, especially in permanent water placements. After water curing, the moulded specimens transferred to an oven at $105^{\circ} \mathrm{C}$ for $72 \mathrm{~h}$, and then were fully immersed in cold water tank for $30 \mathrm{~m}$. Water absorption is calculated by measuring the increase in mass as a percentage of dry mass [31]. The weight of the specimen in fully saturated condition was compared to weight of dried specimen, by average to determine water absorption coefficient. It was found that water absorption is compatible with the quality of concrete faced with harassment or unbound conditions and corrosion, especially those permanently immersed in water, the obtained results in this experiment can be seen in Figure 7.

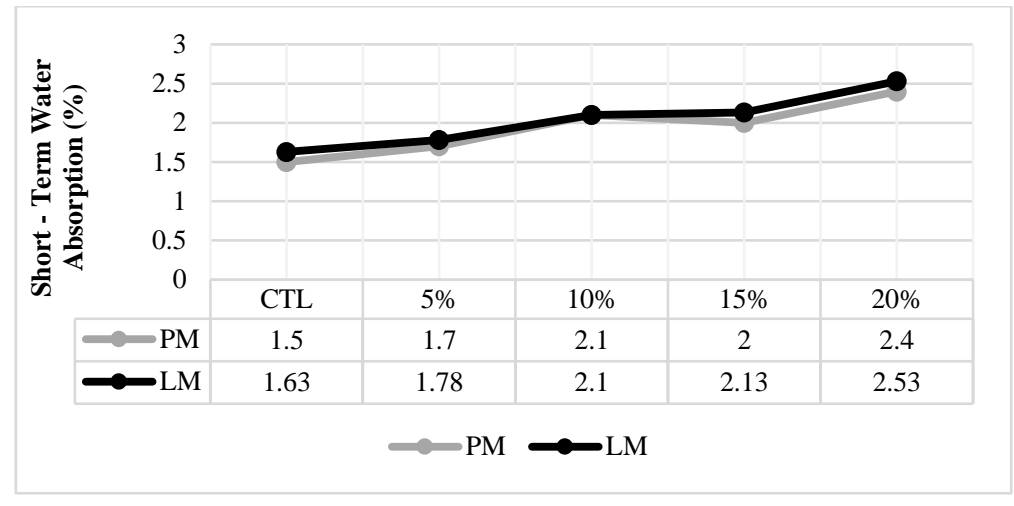

Figure 7. The average water absorption values for concrete blended with pumice and leca

The total water absorption values for mixtures without silica-fume are greater than that of the reference mixture. This result may bring out the opinion that lime stone powder cannot sufficiently block capillary pores and increase water absorption, also can be attributed to more porosity of leca and pumice aggregates. The lowest water absorption ratio caused by the improved aggregate-matrix bond resulting from the formation of a less porous transition zone in the silica fume concrete [32].

\subsection{Rapid Chloride Ion Penetration Test (RCPT)}

One of the most usable methods for evaluation of concrete permeability in contact with chloride ions is methods of RCPT (Rapid Chloride Permeability Test) established according to the provisions of ASTM C1202 standard test method. It is now a well-established method of quality control in Iran [33]. Simple- to conduct is assumed to be the main reason of broad usage of RCPT test method. In this test, the total amount of charge passed by a concrete cube sample under the effect of a $60 \mathrm{~V}$ electric field was measured for $6 \mathrm{~h}$ to show the specimen's permeability. To ensure saturation, all samples were placed in an mmg1 vacuum chamber.

The samples generally placed in a $3 \%$ (or 1.5\%) NACL-solution. The electrical current through the system is automatically recorded. According to Ohm's law this voltage drop is converted to a current: V = R.I = 1.I, as it can be seen in Figure 8 [34].

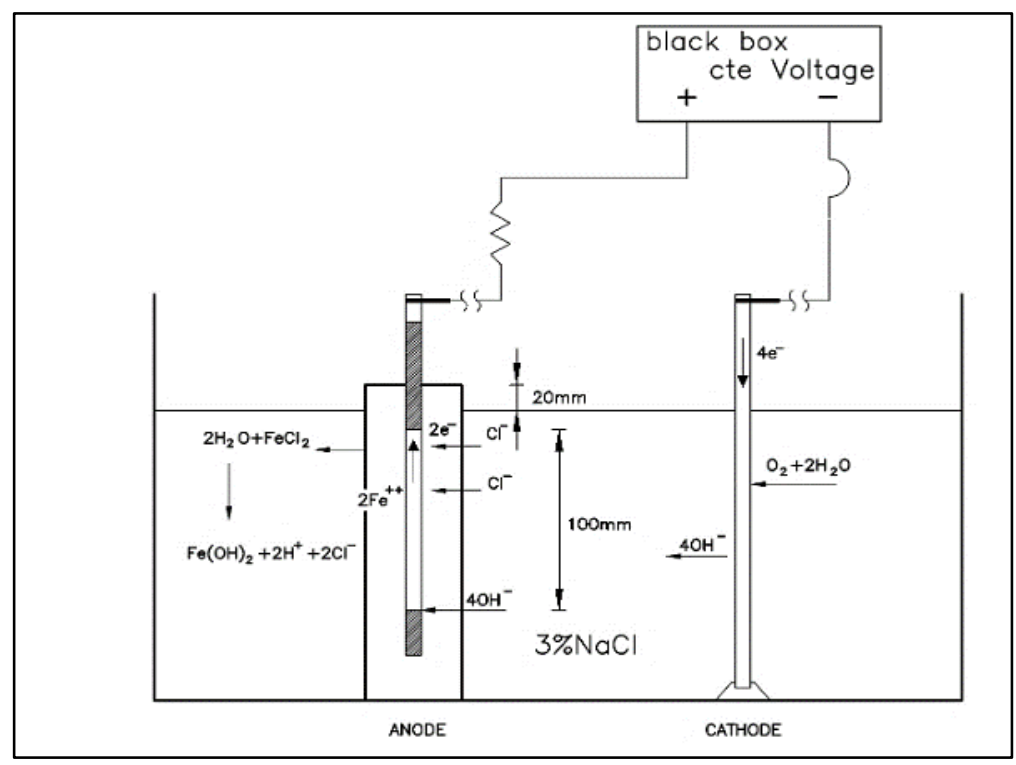

Figure 8. Electronic circuit of the test [34] 
Corrosion progress in concrete is broadly attributed to chloride ions penetration in to the aggregates from contaminated materials, soils or even caused by external impacts from sources such as sea water. In Figure 9 . the total amount of electrical charges measured for 6 mixes by Columbus can be seen. It is thought that CPT tests can be conducted align with diffusion test on the same mixes to ensure reliability of the relationship between the diffusion coefficients. Validity of CPT relies on its ability to allow comparative tests to be conducted on different concrete mixes or on hydrophobic factors based on the diffusion coefficient and chloride penetration times.

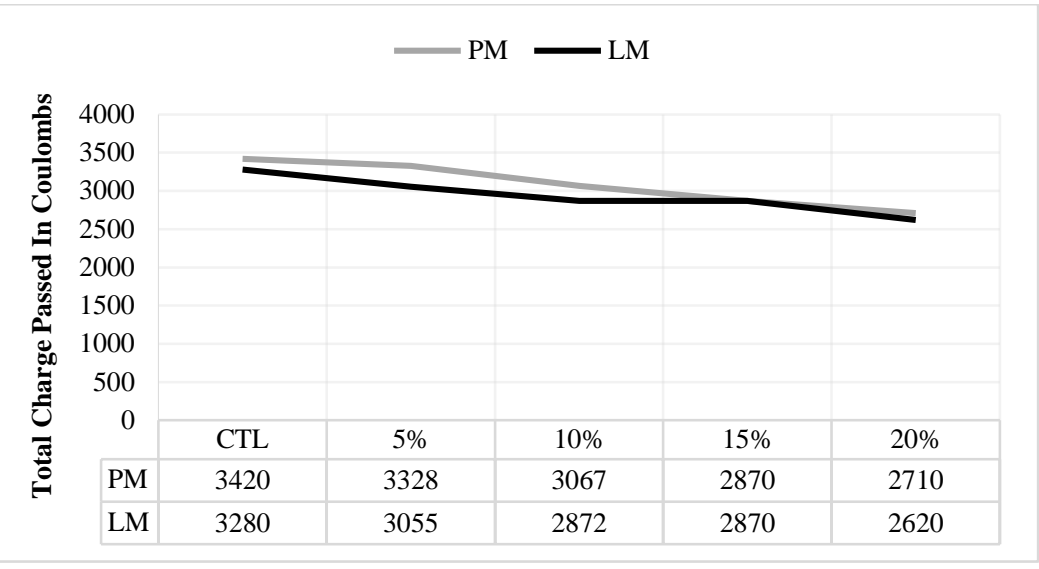

Figure 9. Test results of RCPT for concrete blended with leca and pumice

Table 11. Concrete permeability categorization in contact with chloride ions based on the (ASTM C1202)

\begin{tabular}{cc}
\hline The chloride permeability of concrete & Passing electric flux (Coulomb) \\
\hline Much & $>4000$ \\
Average & $2000 \sim 4000$ \\
Little & $1000 \sim 2000$ \\
Very little & $100 \sim 1000$ \\
Negligible & $<100$ \\
\hline
\end{tabular}

\subsection{Impact Resistance Test}

Impact resistance is the evaluation of partial or whole material's ability to resist toward iterative impacts or high-rate loadings. Impact resistance is of parameters considered to be the most difficult to quantify. To the author's knowledge there may not be a clear relationship between this parameter and the compressive strength. Impact resistance corresponds to concrete resistance subjected to impacts and energy absorption percentage, for example, the number of tolerable beats until returned conditions occur. In this case, the most common test type is falling weight test. Simple- to conduct is the main reason of broad usage of this test to evaluate the behavior of cement-based materials. The number of impacts was recorded until crack at about $2.5 \mathrm{~cm}$ width was observed on lateral surface of specimen in accordance to provisions of ASTM G544 impact resistance test standards. The results are shown in Table 12 and 13.

Table 12. Impact resistance results of the leca samples

\begin{tabular}{cccccc}
\hline $\begin{array}{c}\text { Concrete specific gravity } \\
\mathbf{K g} / \mathbf{m}^{\mathbf{3}}\end{array}$ & \multicolumn{2}{c}{$\begin{array}{c}\text { Impact resistance } \\
\text { First crack/ final failure }\end{array}$} & $\begin{array}{c}\text { Compressive strength } \\
\text { (Mpa) }\end{array}$ & $\begin{array}{c}\text { Age of concrete } \\
\text { (days) }\end{array}$ \\
\hline LM0 & 1570 & 6 & 17 & 35.74 & 28 \\
\hline LM5 & 1434 & 7 & 20 & 33.82 & 28 \\
\hline LM10 & 1446 & 4 & 19 & 28.21 & 28 \\
\hline LM15 & 1502 & 11 & 21 & 30.71 & 28 \\
\hline LM20 & 1558 & 17 & 25 & 37.23 & 28 \\
\hline
\end{tabular}


Table 13. Impact resistance results of the pumice samples

\begin{tabular}{cccccc}
\hline $\begin{array}{c}\text { Concrete specific gravity } \\
\mathbf{K g} / \mathbf{m}^{\mathbf{3}}\end{array}$ & \multicolumn{2}{c}{$\begin{array}{c}\text { Impact resistance } \\
\text { First crack/ final failure }\end{array}$} & $\begin{array}{c}\text { Compressive strength } \\
\text { (Mpa) }\end{array}$ & $\begin{array}{c}\text { Age of concrete } \\
\text { (days) }\end{array}$ \\
\hline PM0 & 1870 & 14 & 27 & 54 & 28 \\
PM5 & 1778 & 10 & 23 & 44.87 & 28 \\
PM10 & 1788 & 9 & 19 & 36.61 & 28 \\
PM15 & 1832 & 11 & 18 & 40.6 & 28 \\
PM20 & 1846 & 8 & 22 & 42.3 & 28 \\
\hline
\end{tabular}

From the results it can be interpreted that a direct relationship exists between compressive strength and impact resistance of samples. The results show that resistance of pumice concrete increased due to its relative delay of failure in strong impacts compared to that of a leca concrete sample. In the following a comparison made between the compressive strength and final failure of given concretes.

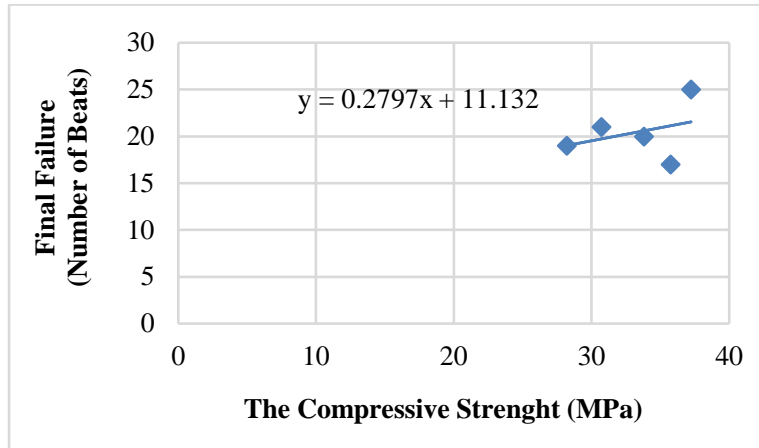

(a)

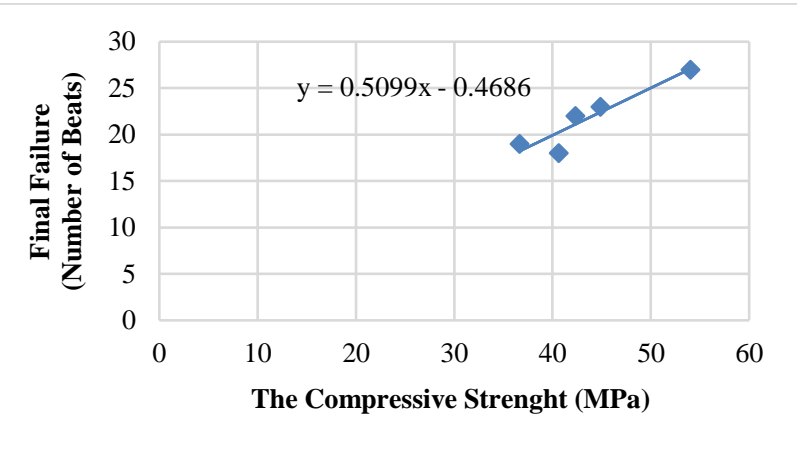

(b)

Figure 10. a) The relationship between the compressive strength and failure of the concrete contains leca; b) The relationship between the compressive strength and failure of the concrete contains pumice

According to the provisions of ACI 544, the final rupture corresponds to complete separation of elements and therefore, complete loss of concrete load bearing capacity. Figure 10. shows linear regression relation between the compressive strength of samples and final rupture at the age of 28 days. Final rupture measurement being performed with a $4.54 \mathrm{~kg}$ hammer and the compressive strength was evaluated in Mpa. As it can be seen from the Figure 10a, $y=$ $0.2797 x+11.132$ defined for leca lightweight concrete presenting that, there was not found any direct relation between strength and number of impacts. For example, the least strength of $28.21 \mathrm{Mpa}$ didn't resulting in the lowest strength of 17 in samples. In general, the more the compressive strength at the age of 28 days, the more the probability of deletion of concrete final rupture. It is opposed to pumice light weight concrete results presented in Figure 10b, in which $y=0.5099 x-0.4686$, shows the linear direct relation between the compressive strength and final failure at the age of 28 days. For example, the highest compressive strength of $54 \mathrm{Mpa}$ could yield the highest impact resistance by 27. Comparison of two figures show that the correlation coefficient of pumice light weight concrete $R^{2}=0.8663$ is much larger. There was not found any clear relation between addition of limestone powder and impact resistance. A concrete limestone powder disk is separated from the cylindrical sample. The impact causes dent which could be observed at the center of the disk and initial cracks evolving in $60^{\circ}$ sectorial form through the disk. There is a decreased possibility to find significant differences between the number of final impacts in the reference sample and powdered limestone concrete samples. It can be interpreted that energy absorption capability and concrete ductility did not change considerably. It seems that light weight concrete with the capability of impact resistance being achieved by using various fibers.

\subsection{Weight Alterations of the Specimens Immersed in Sulphuric Acid}

Sulphuric acid corrosion in structures and concrete sewer pipes after a few years of construction is yet to be resolved satisfactorily by weighting the effects of these solutions on concrete in terms of mass change, residual compressive strength and duration of placement. In this case, a research by looking the ways of improving acid resistance of Portland cement based concretes evaluated the effects of using some binders and supplementary materials such as limestone conducted by [35]. Weight changes and the residual compressive strength of two $10 \mathrm{~cm}$ cube specimens was calculated 
by passing $28 \mathrm{~d}$ of immersion in $\mathrm{PH}=3 \%$ sulphuric acid solution. The acidic ratio of the solution was controlled by $\mathrm{PH}$ meter device, to keep it by $\mathrm{PH}=3$. The results are presented below:

Table 14. Weight alterations of the specimens immersed in sulphuric acid for concrete blended with leca

\begin{tabular}{cccc}
\hline Mix plan & $\begin{array}{c}\text { Specimens' weight } \\
\text { before acid immersion }\end{array}$ & $\begin{array}{c}\text { Specimens' weight after } \\
\text { acid immersion }\end{array}$ & $\begin{array}{c}\text { Reduction of Weight at } \\
\text { an age of 28 d (\%) }\end{array}$ \\
\hline LM0 & 1570 & 1556 & 0.89 \\
LM5 & 1434 & 1419 & 1.04 \\
LM10 & 1446 & 1424 & 1.52 \\
LM15 & 1502 & 1481 & 1.39 \\
LM20 & 1558 & 1537 & 1.34 \\
\hline
\end{tabular}

Table 15. Weight of the specimens immersed in sulphuric acid for concrete blended with pumice

\begin{tabular}{cccc}
\hline Mix plan & $\begin{array}{c}\text { Specimens' weight } \\
\text { before acid immersion }\end{array}$ & $\begin{array}{c}\text { Specimens' weight after } \\
\text { acid immersion }\end{array}$ & $\begin{array}{c}\text { Reduction of Weight at } \\
\text { an age of 28 d (\%) }\end{array}$ \\
\hline PM0 & 1870 & 1856 & 0.74 \\
PM5 & 1778 & 1760 & 1.01 \\
PM10 & 1788 & 1771 & 0.95 \\
PM15 & 1832 & 1812 & 1.09 \\
PM20 & 1864 & 1843 & 1.6 \\
\hline
\end{tabular}

Tests was conducted on two $10 \mathrm{~cm}$ cube specimens (from each mix plan two specimens were fully immersed in acid solution). The results show that, addition of limestone powder increases acid resistance, thereby increasing the weight loss and compressive strength. It was concluded that partial replacement of cement by $15 \%$ limestone powder leading to a decrease in compressive strength up to $10 \%$ in both types of blended light weight concretes.

\subsection{The Compressive Strength of Specimens Immersed in Sulphuric Acid}

Pumice and leca based concrete samples immersed in sulphuric acid at an age of $28 \mathrm{~d}$, to be compared to normal 28 $\mathrm{d}$ tap water curing. The results can be observed below.

Table 16. The compressive strength alterations of the specimens immersed in sulphuric acid for concrete incorporated with leca at an age of $28 \mathrm{~d}$.

\begin{tabular}{cccc}
\hline Mix plan & $\begin{array}{c}\text { Compressive strength at an age } \\
\text { of 28 days of tap water curing }\end{array}$ & $\begin{array}{c}\text { Compressive strength at an age } \\
\text { of 28 days of acid immersion }\end{array}$ & $\begin{array}{c}\text { Reduction of compressive strength } \\
\text { at an age of 28 days }(\%)\end{array}$ \\
\hline LM0 & 35.74 & 33.7 & 6 \\
LM5 & 33.82 & 30.54 & 10 \\
LM10 & 28.21 & 27.33 & 5 \\
LM15 & 30.71 & 25.41 & 11 \\
LM20 & 37.23 & 32.69 & 12 \\
\hline
\end{tabular}


Table 17. The compressive strength alterations of the specimens immersed in sulphuric acid for concrete incorporated with pumice at an age of $28 \mathrm{~d}$.

\begin{tabular}{cccc}
\hline Mix plan & $\begin{array}{c}\text { Compressive strength at an age } \\
\text { of 28 days of tap water curing }\end{array}$ & $\begin{array}{c}\text { Compressive strength at an age } \\
\text { of 28 days of acid immersion }\end{array}$ & $\begin{array}{c}\text { Reduction of the compressive strength } \\
\text { at an age of 28 days (\%) }\end{array}$ \\
\hline LM0 & 35.74 & 33.7 & 6 \\
LM5 & 33.82 & 30.54 & 10 \\
LM10 & 28.21 & 27.33 & 5 \\
LM15 & 30.71 & 25.41 & 11 \\
LM20 & 37.23 & 32.69 & 12 \\
\hline
\end{tabular}

It can be observed from the results that immersion of this type of concrete in to acid solutions lead to a slight improved compressive strength as a function of sulphuric acid penetration into specimens to be reacted with cement paste and coarse aggregates. When the strength of different mixes is compared it can be concluded that this variation depends on mixture type and limestone powder amount. Partial replacement of cement by powder limestone yield suitable strength properties that can be interpreted from slight changes in samples' weight were immersed in acid solutions.

\subsection{The Compressive Strength Under High Temperature}

Compressive strength test was carried out on cube specimens of LM and PM (basic mixtures) at an age of 28 days. The residual compressive strength measurement made after specimens were exposed to elevated temperatures ranging from $800-100^{\circ} \mathrm{C}$, then gradual cooling in laboratory environment. Figure 11 . shows the residual compressive strength of light weight concrete blended with leca and pumice in a variety of temperatures, respectively. It can be interpreted from the results that elevated temperatures is the reason of strength loss. Above $400^{\circ} \mathrm{C}$, strength drop is faster by about $52.21 \%$ and $53.59 \%$ by the initial strength, respectively, while strength loss is not sharp at lower temperatures.

The replacement of cement by limestone powder increase the decrease in compressive strength after exposure to elevated temperature, this resulted by the dense micro structures which led to the build-up of high internal pressure during heating [36].

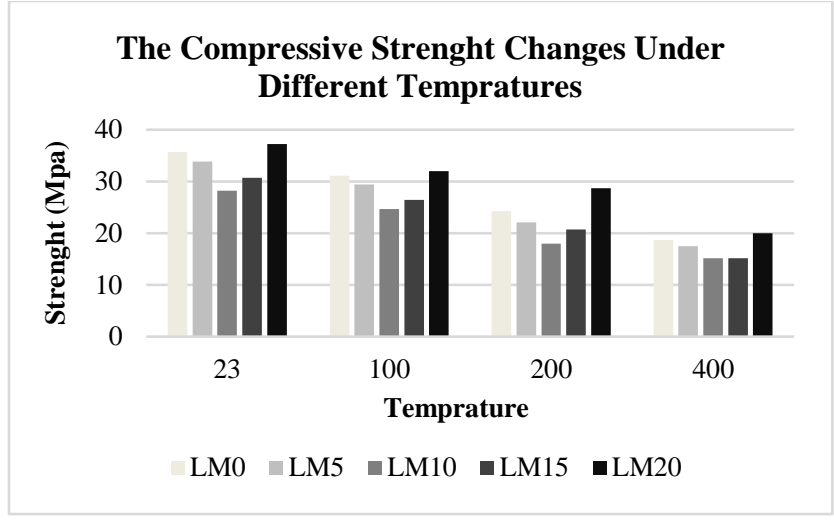

(a)

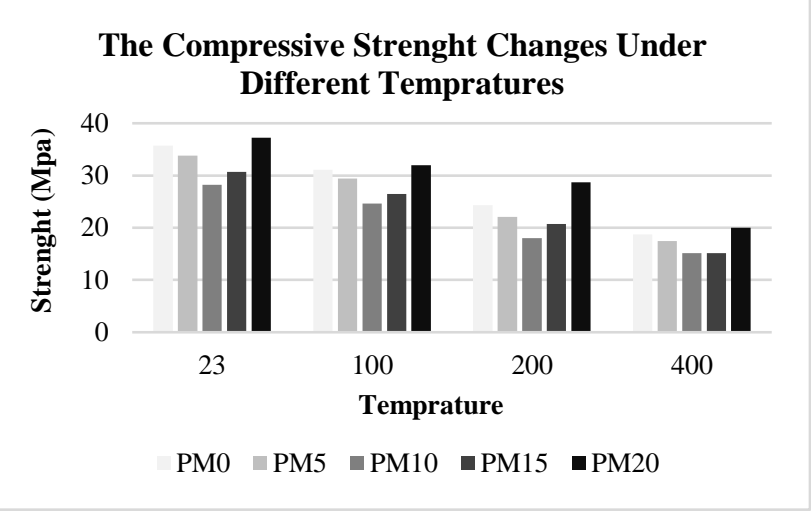

(b)

Figure 11. a) Compressive strength variations at different temperatures for leca concrete (Mpa); b) Compressive strength variations at different temperatures for pumice concrete (Mpa)

In presence of different temperatures, both types of concretes exhibit the similar strength loss, for concrete contains leca this amount is slightly more than that of a pumice based concrete in similar situations, which can be attributed to more fire resistance of its light weight aggregates. Carte should be taken that in elevated temperatures more than $200^{\circ} \mathrm{C}$, deviation from structural behaviour may be observed in both types of concretes specifically in leca concrete. Incorporation of powder limestone and micro-silica in concrete assumed to increase the compressive strength compared to the reference sample in high temperatures.

\section{Conclusion}

The following conclusions can be drawn from this study:

- High stable light weight concrete contains lime stone powder and micro- silica fitted to achieve as economic and environmental benefits as possible. 
- Simultaneous partial replacement of cement with 5\% powdered limestone combined with the same amount of micro- silica provide suitable mechanical and durability properties. While the optimal level of replacement in terms of durability properties of leca based light- weight concrete obtained $20 \%$.

- Water absorption coefficient of specimens incorporated with $20 \%$ powdered limestone and w/c ratio of 0.37 was between 1.5 to $2.5 \%$.

- The compressive strength of compounded concrete containing micro-silica and up to $20 \%$ powdered limestone decreased by $21 \%$ in pumice concrete, while increased up to $4 \%$ in leca concrete.

- Chloride ions penetration results found to be correlated with increased amount of powdered-limestone, such that $20 \%$ decrease in chloride ions penetration observed comparing to the reference sample.

- Durability tests results claimed that strength of concrete did not change significantly in contact with acidic solutions, such that the maximum strength loss obtained up to $12 \%$ comparing to normal solutions.

- Compressive strength appraisal of specimens exposed to temperatures over $200^{\circ} \mathrm{C}$ indicated that the more the temperature was elevated, the more the strength decreased even up to $50 \%$ comparing to normal temperature (23 $\left.{ }^{\circ} \mathrm{C}\right)$.

- Ideally, experiments and related studies regarding industrial wastes or supplementary materials have tried to prompt cement industry applying clean energy, and establishing sustainable development.

- Field experience with water absorption coefficient of specimens contains $20 \%$ powdered limestone and w/c ratio of 0.42 was between 1.63 to $2.53 \%$.

\section{References}

[1] Mehta, P. Kumar. "Advancements in concrete technology." Concrete International 21, no. 6 (1999): 69-76.

[2] Naik, Tarun R. "Sustainability of concrete construction." Practice Periodical on Structural Design and Construction 13, no. 2 (2008): 98-103.

[3] Meyer, Christian. "The greening of the concrete industry." Cement and concrete composites 31, no. 8 (2009): 601-605.

[4] Monteiro, Paulo. Concrete: microstructure, properties, and materials. McGraw-Hill Publishing, 2006.

[5] Benhelal, Emad, Gholamreza Zahedi, Ezzatollah Shamsaei, and Alireza Bahadori. "Global strategies and potentials to curb CO 2 emissions in cement industry." Journal of cleaner production 51 (2013): 142-161.

[6] Nomeli, Mohammad A., and Amir Riaz. "The potential for carbon dioxide sequestration in subsurface geological formations." Handbook of Clean Energy Systems (2015).

[7] Struble, Leslie, and Jonathan Godfrey. "How sustainable is concrete." In International workshop on sustainable development and concrete technology, pp. 201-211. 2004.

[8] Clarke, John L., ed. Structural lightweight aggregate concrete. CRC Press, 2002.

[9] Document B 92/17688. Eupropean draft standard specification for light weight aggregates. 1992.

[10] Farahani, Javad Nodeh, Payam Shafigh, Belal Alsubari, Sheida Shahnazar and HBM. Engineering properties of lightweight aggregate concrete containing binary and ternary blended cement. J Clean Prod 2017;149:976-88.

[11] Tanyildizi, Harun and AC. The effect of high temperature on compressive strength and splitting tensile strength of structural lightweight concrete containing fly ash. Constr Build Mater 2008;22:2269-75.

[12] Katip I, Universitesi C, Ugur I. The effects of different fine and coarse pumice aggregate / cement ratios on the structural concrete properties without using any admixtures. Cem Concr Res 2005;35:1859-64. doi:10.1016/j.cemconres.2004.08.003.

[13] Akeiber, Hussein, Payam Nejat, Muhd Zaimi Abd Majid, Mazlan A. Wahid, Fatemeh Jomehzadeh, Iman Zeynali Famileh, John Kaiser Calautit, Ben Richard Hughes and SAZ. A review on phase change material (PCM) for sustainable passive cooling in building envelopes. Renew Sustain Energy Rev 2016;60:1470-97.

[14] Alshihri MM, Azmy AM, El-Bisy MS. Neural networks for predicting compressive strength of structural light weight concrete. Constr Build Mater 2009;23:2214-9. doi:10.1016/j.conbuildmat.2008.12.003.

[15] Arezoumandi, Mahdi and JSV. Effect of fly ash replacement level on the shear strength of high-volume fly ash concrete beams. J Clean Prod 2013;59:120-30.

[16] Mehta PK. Supplementary Cementing Materials for Sustainable Development. High-performance, high-volume fly ash concrete: materials, mixture proportioning, properties, construction practice, and case histories. Suppementary Cem Mater Sustain Dev 2002. 
[17] Kasselouri, V. and GP. Stabilization of magnesia cements by adding flying ashes and slag. Silic Indust 1977;1:13-7.

[18] Howard, Isaac L., Jay Shannon, V. Tim Cost and MS. Davis wade stadium expansion and renovation: Performance of concrete produced with portland-limestone cement, fly ash, and slag cement. J Mater Civ Eng 2015;27.

[19] Antoni, M., J. Rossen, F. Martirena and KS. Cement substitution by a combination of metakaolin and limestone. Cem Concr Res 2012;42:1579-89.

[20] Heikal, M., H. El-Didamony and MSM. Limestone-filled pozzolanic cement. Cem Concr Res 2000;30:1827-34.

[21] Ajay V, Rajeev C. Effect of Micro Silica on The Strength of Concrete with Ordinary Portland Cement. Res J Eng Sci _ISSN Sept Res J Eng Sci 2012;1:2278-9472.

[22] Cyr, Martin, Philippe Lawrence and ER. Mineral admixtures in mortars: quantification of the physical effects of inert materials on short-term hydration. Cem Concr Res 2005;35:719-30.

[23] De Weerdt, Klaartje, M. Ben Haha, G. Le Saout, Knut O. Kjellsen, Harald Justnes and BL. Hydration mechanisms of ternary Portland cements containing limestone powder and fly ash. Cem Concr Res 2011;41:279-91.

[24] Bentz, Dale P., Chiara F. Ferraris, Scott Z. Jones, Didier Lootens and FZ "Limestone and silica powder replacements for cement: E performance. Limestone and silica powder replacements for cement: Early-age performance. Cem Concr Compos 2017;78:43-56.

[25] Oey, Tandré, Aditya Kumar, Jeffrey W. Bullard, Narayanan Neithalath and GS. The filler effect: the influence of filler content and surface area on cementitious reaction rates. J Am Ceram Soc 2013;6:1978-90.

[26] Hariharan AR, Santhi AS, Ganesh GM. Study on Strength Development of High Strength Concrete Containing Fly ash and Silica fume. Int J Eng Sci Technol 2011;3:2955-61.

[27] Liu S, Yan P. Effect of limestone powder on microstructure of concrete. J Wuhan Univ Technol Mater Sci Ed 2010;25:328-31. doi:10.1007/s11595-010-2328-5.

[28] Liu SH, Gao ZY, Rao MJ. Study on the Ultra High Performance Concrete Containing Limestone Powder. Adv Mater Res 2011;250-253:686-9. doi:10.4028/www.scientific.net/AMR.250-253.686.

[29] Mazloom M, Ramezanianpour AA, Brooks JJ. Effect of silica fume on mechanical properties of high-strength concrete. Cem Concr Compos 2004;26:347-57. doi:10.1016/S0958-9465(03)00017-9.

[30] Lothenbach, B., Saout, G., Gallucci, E., Scrivener K. Influence of limestone on the hydration of Portland cements. Cem Concr Res 2008;38:848-860.

[31] Neethu Susan Mathew SU. Effects of Copper Slag as Partial Replacement for Fine Aggregate in Geopolymer Concrete. IOSR J Mech Civ Eng 2016:73-7.

[32] Türkel S, Altuntaş Y. The effect of limestone powder, fly ash and silica fume on the properties of self-compacting repair mortars. Sadhana - Acad Proc Eng Sci 2009;34:331-43. doi:10.1007/s12046-009-0011-3.

[33] ASTM Publication US. ASTM Standard C1202, “Standard Test Method for Electrical Indication of Concrete's Ability to Resist Chloride Ion Penetration 2007.

[34] Poupeleer, A. S., and D. Van Gemert. "Evaluation Of Accelerated Chloride Ion Diffusion Test And Applicability Of Fick's Second Law.".

[35] Song, X. J., Z. T. Chang, M. Marosszeky and RM. Enhancing acid resistance of concrete by varying cement and aggregate types. Concr. 3rd Millenn. Aust., 2003, p. 851-62.

[36] Poon, Chi-Sun, Salman Azhar, Mike Anson and Y-LW. Comparison of the strength and durability performance of normal-and high-strength pozzolanic concretes at elevated temperatures. Cem Concr Res 2001;31:1291-300. 